\title{
Ear Tag
}

National Cancer Institute

\section{Source}

National Cancer Institute. Ear Tag. NCI Thesaurus. Code C98919.

A small preauricular skin tag. 